\title{
Exploring the Relationship between Listening Strategies Used by Iranian EFL Senior High School Students and Their Listening Comprehension Problems
}

\section{Ehsan Namaziandost ${ }^{1 *}$, Ava Imani ${ }^{2}$, Sasan Sharafi ${ }^{3}$, Reza Banari ${ }^{4}$}

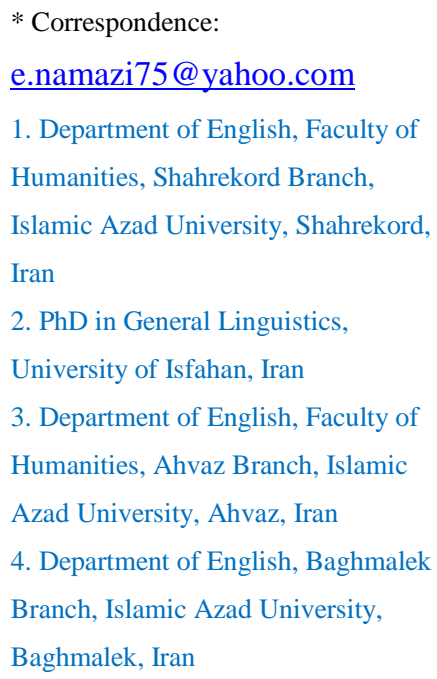

Received: 18 September 2019

Revision: 17 November 2019

Accepted: 6 December 2019

Published online: 20 March 2020

\begin{abstract}
The present research investigated listening strategy utilization among 60 Iranian EFL senior high school learners. Furthermore, it tried to distinguish 1) the strategies utilized all the more frequently by learners, 2) the relationship between listening strategy utilization, and listening comprehension problems. In this study, problems included input, context, listener, process, affect, and task problems while the listening strategies comprised of cognitive, meta-cognitive, and socio-affective strategies. To gather the required information, a survey was dispersed among the members. After collecting the information and analyzing them through SPSS software, the outcomes uncovered that 'input' and 'affect' were two primary listening comprehension problems the students experienced. Results additionally showed that the principle listening strategy utilized by students was metacognitive strategy. The connection between listening problems and technique utilized among the students was measurably critical and negative. Results suggest that it is essential for second language educators to know about the distinctive listening problems to empower listeners to use the suitable techniques.
\end{abstract}

Keywords: listening comprehension problems, listening strategies, $\underline{\text { cognitive strategies, meta-cognitive strategies, socio-affective strategies }}$ 


\section{Introduction}

A language is totally educated and evaluated in terms of four fundamental language abilities of listening, speaking, reading, and writing. Of these four abilities, listening as a receptive skill, is considered as an ability that can be acquired normally through speaking and reading (Lau, 2016), so it is regularly disregarded or ineffectively educated in most classroom where English is instructed as a Second or Foreign Language (ESL/EFL) (Vandergrift, 1997). Indeed, the most recent research in listening comprehension features the way that listening skill is problematic for some learners and thus teachers should see it as a foundation and establishment for achievement in language learning (Kassem, 2015; Shakibaei, Shahamat, \& Namaziandost, 2019). Along these lines, language educators need to enable students to expand listening comprehension strategies with the aim not only to upgrade the comprehensible input but also improve the advancement of other language abilities.

Listening comprehension techniques are characterized as "cognizant designs to oversee approaching discourse, especially when the audience realizes that he/she should make up for deficient information or incomplete comprehension" (Rost, 2011, p.236). They are arranged as psychological, metacognitive, and socio-full of feeling techniques, which center around taking care of the problems of students' obtaining, stockpiling, recovery, and utilization of information (Vandergrift, 1997). Psychological strategies are discrete learning exercises (Abedi, Namaziandost, \& Akbari, 2019; Serri, Boroujeni, \& Hesabi, 2012) to deal with the learning assignments or complete a specific errand, including inferencing, elaboration, rundown, interpretation, move, reiteration, resourcing, gathering, note taking, substitution, and reasoning/enlistment (Namaziandost, Neisi, Mahdavirad, \& Nasri, 2019; Vandergrift, 1997). Metacognitive strategies are "the capacity of students to control their musings and to manage their own learning” (Vandergrift \& Goh, 2012, p.5), including arranging, observing, assessment, and problem distinguishing proof (Vandergrift, 1997). Socio-full of feeling techniques are exercises to reinforce positive passionate mentalities toward language learning (Chamot \& O’Malley, 1987; Namaziandost, Neisi, Kheryadi, \& Nasri, 2019). They can be partitioned into five classes: addressing for explanation, collaboration, bringing down nervousness, self-support, and taking passionate temperature (Nasri, Namaziandost, \& Akbari, 2019; Vandergrift, 1997).

Of these listening comprehension strategies, metacognitive strategies can assist learners to activate their thinking and improve their learning performance in most cases. They are not the theoretical orientation, but the methodology to cultivate the ability to self-regulated learning. Graham and Santos (2015) indicated that students would be able to control over their learning process if they have the opportunity to learn about the metacognitive strategy use. Research on listening comprehension strategies have mainly focused on four aspects: (1) identify and classify strategies used by EFL/ESL learners; (2) investigate the frequency of strategies indifferent groups based on gender, language proficiency level; (3) examine the relationship between strategy use and different variable (e.g., anxiety, self-efficacy); and (4) examine the reflection of strategy instruction on listening comprehension achievement (Kassem, 2015; Namaziandost, Shatalebi, \& Nasri, 2019).

Regardless of the developing assemblage of concentrates on the various parts of L2 listening, barely any looks into have focused on distinguishing listening problems among second language learners (Abedi, Keshmirshekan, \& Namaziandost, 2019; Chen, 2013). Most schools, as communicated by Hamouda (2012), center around language structure and jargon instead of listening. This examination goes above and beyond by attempting to explore listening problems comparable to listening techniques. There is minimal thought about the connection between these factors among Iranian EFL learners.

Listening comprehension is tricky for most second language learners. Specialists ascribe this to factors including attributes of the audience, content, undertaking, and strategy (Hashemifardnia, Namaziandost, \& Shafiee, 2018; Rubin, 1994). Goh (2000) experimentally perceived a few obstructions that hamper EFL listening comprehension. These are emotional obstructions, habitudinal boundaries, information preparing hindrances (e.g., handling speed, input maintenance, translation), English capability, key boundaries (e.g., having problems directing the best possible techniques), conviction obstructions (e.g., going to each word or requesting full comprehension of content), and material hindrances (e.g., trouble level of materials, content class, themes) (Namaziandost, Saberi Dehkordi, \& Shafiee, 2019).

To overcome these wellsprings of trouble, second language learners are required to be vital audience members. The territory of vital listening has not so far got the due consideration in the Iranian setting. In like manner, the present investigation expected to investigate the listening perception techniques that Iranian EFL learners use all the more 
every now and again when they listen to English material. Besides, the investigation examined the connection between EFL learners' listening system utilization and listening comprehension.

\subsection{Research Questions}

The research questions of this study are as follows:

RQ1. What are the listening problems of Iranian advance EFL learners?

RQ2. Is there a significant relationship between the listening strategies used by Iranian EFL senior high school students and their listening comprehension problems?

\subsection{Research Hypothesis}

Based on the research questions, the following null hypothesis was formulated:

H0 1. There is not any significant relationship between listening strategies used by Iranian EFL senior high school students and their listening comprehension problems

\section{Review of the Literature}

\subsection{Listening Comprehension}

It is very important to emphasize the difference between "listening" and "listening comprehension." According to Hasan (2000), listening is a process of just listening to the message without interpreting and responding to the text, while listening comprehension is a process which includes meaningful interactivity and an overall comprehension of the text. Holden (2004, p.257) characterizes listening comprehension as "a functioning strategy where the audience must segregate among sounds, get words and sentence structure, decipher inflection and other prosodic intimations, and hold information assembled long enough to decipher it in the specific circumstance or setting in which the trade happens." As can unmistakably be seen from the clarification, listening is a complex process during which audience members are positively not inactive, as has been thought for quite a while, however, in opposite, they need a lot of focus and mental exertion. "Listening comprehension is a lot of exceptionally coordinated aptitudes, all of which assume a significant job during the time spent language procurement" (Holden, 2004, p.259). O'Malley, Chamot, and Kupper (1989) likewise characterize listening appreciation as a functioning strategy "in which audience members select information from the sound-related or potentially visual hints and relate the information to existing information in their long-term memory for better comprehension and fathoming what they hear." Byrnes (1984, p.55) describes listening comprehension as an "exceptionally unpredictable critical thinking action" that can be separated into a lot of unmistakable sub-abilities.

Listening assumes a significant job in correspondence in individuals' day by day lives. As Guo and Wills (2006) state "it is the medium through which individuals increase a huge extent of their training, their information, their comprehension of the world and human undertakings, their beliefs, feeling of qualities" (p.3). As per Mendelson (1994) "of the total time spent on imparting, listening takes up 40-50\%; speaking 25-30\%; reading 11-16\%; and writing on $9 \%$ " (p.9). Accentuating the significance of listening language learning, Peterson (2001) states that "no other kind of language input is anything but difficult to process as communicated in language, got through listening ... through listening, students can construct a familiarity with the inter-workings of language frameworks at different levels and in this way set up base for progressively familiar beneficial abilities" (p.87).

Rost (1994) clarifies the significance of listening language classroom as follows:

1. Listening is indispensable in the language classroom since it gives contribution to the student. Without comprehension contribution at the correct level, any adapting just can't start.

2. Communicated in language gives a method for cooperation to the student. Since students must communicate to accomplish comprehension, access to speakers of the language is basic. In addition, students' inability to comprehend the language they hear is an impulse, not a snag, to communication and learning.

3. Valid communicated in language introduces a test for the student to comprehend language as local speakers really use it.

4. Listening practices give instructors a method for causing learners to notice new structures (jargon, sentence structure, new connection designs) in the language (p.141-142). 
To outline, listening has a significant job both in day by day life and in scholastic settings as it is vital for individuals to continue compelling correspondence. Accentuating the significance of listening, Namaziandost, Hafezian, and Shafiee (2018) express that listening aptitudes are as significant as talking abilities since individuals can't convey eye to eye except if the two sorts of abilities are grown together. Listening aptitudes are likewise significant for learning purposes since through listening learners get information and addition experiences (Ziafar \& Namaziandost, 2019).

\subsection{Listening Problems}

EFL students have significant problems in English listening comprehension because of the way that colleges give more consideration to English language structure, perusing, and jargon. Listening and talking aptitudes are not significant pieces of many course books or educational programs and educators don't appear to focus on these abilities while structuring their exercises. Most instructors underestimate it and accept that it will grow normally inside the strategy of language learning. Persulessy (1988) states that one reason for the assessment that listening is an ability that will in general be ignored is the inclination among language educators that this aptitude is naturally procured by the student as he figures out how to communicate in the language. Most instructors likewise accept listening is synonymous to breathing-programmed (Namaziandost \& Nasri, 2019a; Persulessy, 1988). Another motivation behind why this aptitude isn't given genuine consideration is the way that ineptitude in it is anything but difficult to stow away through gesturing and shaking of the head, which may give the impression of seeing, even there is none. Still another explanation is that sound lingual courses give the feeling that they are instructing listening when in actuality they are showing different aptitudes.

Despite the fact that the announced problems were identified with audience factors or strategy factors, they were for the most part limited to the lower level handling problems, for example, troubles in recognizing words they know and lumping floods of discourse and fixation. This may propose that most learners have obliged information on their methods for managing listening information and little consciousness of the genuine problems happening during preparing. Accordingly, perception ordinarily separates at the low-level of preparing, which restrains audience members from showing up at effective comprehension. These listening problems have for quite some time been overlooked and stayed uncertain in the regular instructing of listening, which just includes working on responding to the listening test questions and clarifying importance (Karami, \& Bagheri, 2014; Namaziandost \& Ahmadi, 2019). It is basic to guide and help students to process listening assignments all the more proficiently and viably so as to beat impediments that happen during the listening strategy. One of the most significant approaches to assist students with accomplishing fruitful listening is to control them to raise their familiarity with their listening problems and utilize successful listening strategies.

\subsection{Strategies for Listening Comprehension}

During the time spent learning EFL, listening is viewed as one of the hardest language abilities to be created, on the grounds that when learners need to listen, they need to confront numerous troubles to comprehend the message totally. Rahimirad and Zare-ee (2015) noticed various troubles that can be gone up against in listening assignments, for example, obscure jargon, new subjects, quick discourse rate, and new or various accents. These are errands learners need to confront each day in the classroom. Learners listen; however, they may not comprehend the various articulations or accents from the speakers. For instance, numerous individuals who originate from various nations communicate in English as their subsequent language, yet they have a specific English inflection impacted by their native language, which is difficult for individuals to impersonate or to comprehend. Likewise, when learners are engaged with a listening action and they can't comprehend the significance of certain words, they may lose fixation and stop the movement. Thus, students can't finish the listening task on schedule.

Furthermore, it is increasingly hard to finish the listening movement when learners don't have earlier information about the subject, on the grounds that the information is obscure to them. Learners lose time attempting to finish the assignment. However, among all the troubles that have been referenced previously, the one that causes the most effect on EFL students is quick pace of discourse (Bidabadi \& Yamat, 2011; Mirshekaran, Namaziandost, \& Nazari, 2018; Pourhosein \& Ahmadi, 2011). At the point when learners are engaged with a listening task, in most of the cases they need the speaker to talk gradually, and the educator at that point plays the sound material more than once. It is fundamental and critical that learners figure out how to accomplish the advancement of the listening appreciation ability to procure the new language and to comprehend the message totally. The utilization of listening techniques is useful to build up the listening comprehension skill required to learn and hold information. 


\section{Methodology}

\subsection{Participants}

The sample of the study consisted of 60 Iranian male participants between the ages of 15 and 17 years. They were selected among 80 senior high school students in Ahvaz Iran. All of them were at upper-intermediate level of proficiency in English based on the results of Oxford Quick Placement Test (OQPT). The sample of the present study was chosen through purposive, convenient sampling (Etikan, Musa, \& Alkassim, 2016); purposive in the sense that only intermediate EFL learners were recruited, and convenient in the sense that the participants were easily accessible ones who were intended to be representative of the whole population as diverse as possible selected from among those who attended English courses at a high school in Iran. The participants were made assure that their personal information would be kept confidential.

\subsection{Instruments}

\subsubsection{Oxford Quick Placement Test (OQPT)}

The researchers employed the Oxford Quick Placement Test as the first instrument of the study to homogenize the learners in the advance level. The test included 60 items in a multiple-choice format which was used to assess the participants' degree of homogeneity prior to the study. OQPT could aid the researchers to have a greater comprehension of what level (i.e., elementary, pre-intermediate, intermediate, advanced) the participants were at. According to this test, the learners whose scores were between 37 and 48 (out of 60) were considered as the intermediate learners.

\subsubsection{Questionnaire of Beliefs on English Language Listening Comprehension Problems (Q-BELLP) (Lotfi, 2012)}

The Q-BELLP was created to recognize listening perception problems among Iranian EFL students. There are fortyitems in the survey with six unmistakable components: process, input, audience, undertaking, influence, and setting. The main factor, marked strategy, comprises of 12 items and mirrors students' convictions about listening problems related with various parts of listening comprehension strategy. Strategy here alludes to "the manner by which students utilize various types of signs to decipher what they hear" (Rubin, 1994, p.210). Truth be told, items stacking on this factor depict students' convictions about problems identified with two sorts of preparing recognized by Rubin (1994); that is, utilizing intellectual and metacognitive methodologies while listening. The subsequent factor, named input, comprises of nine items and speaks to students' convictions about problems identified with various parts of aural information. Contribution here is characterized as the objective language talk that arrives at the students' sound-related framework (Field, 2008; Namaziandost, Sabzevari, \& Hashemifardnia, 2018) in unidirectional listening.

This factor contains students' convictions about problems identified with such info attributes as jargon, discourse clearness, syntactic structure of the content, discourse rate, prosodic highlights, emphasis, delay, and content length (Lotfi, 2012). The third factor, named audience, includes 10 items and mirrors students' convictions about audience members' attributes recognized in the writing as having a significant effect on L2 students' listening cognizance (Hasan, 2000). The factor henceforth contains students' convictions about problems related with qualities, for example, consideration, mentality, and memory. The fourth factor, marked errand, incorporates three items and mirrors students' convictions about problems related with qualities of listening undertakings. Assignment qualities allude to "variety in the reason for listening and related reactions" (Rubin, 1994, p.199).

Items stacking on this factor speak to students' convictions about listening problems related with task type and kind of reactions requested while addressing worldwide and neighborhood questions. The fifth factor, marked effect, comprises of four items and mirrors students' convictions about problems identified with emotional component of listening. Students' convictions about their full of feeling reactions to occurrences of cognizance disappointment are reflected in the initial two items of this factor. The other two items of this factor mirror students' convictions in regards to the degree of nervousness they involve with L2 listening. The 6th factor, marked setting, mirrors students' convictions about horrible attributes of the learning setting influencing listening cognizance. The factor contains two items mirroring students' convictions about the unfavorable impact of distracters accessible in the learning setting on their listening comprehension. The items under this factor explicitly mirror students' conviction about the listening challenges brought about by such logical highlights as second rate machine to play chronicles and acoustically unacceptable spaces for the utilization of recorded materials. 
It must be referenced that the respondents' levels for all these subscales were considered as far as 5 Likert scales running from never to consistently. Since every decision right now questionnaire had been doled out a worth (Always $=5$, Usually $=4$, Sometimes $=3$, Seldom $=2$, and Never $=1$ ), the mean score of every survey was contrasted with the normal score of the decisions (for example 3.00). Henceforth, if the mean score of a survey subscale was under 3.00, the respondents would in general can't help contradicting that announcement. In actuality, a mean score above 3.00 demonstrated the respondents' tendency to agree or concur with that subscale.

The Cronbach's alpha estimations of six elements are as per the following: Process (.90), input (.86), audience (.87), task (.84), effect (.72), and setting (.66) (Lotfi, 2012). Besides, the dependability of the thing review was evaluated by Yaseen and Nimehchisalem (2016) utilizing the Cronbach's alpha coefficient and it was .82, which shows a worthy interior consistency. The master judges were four college educators who had five years of involvement with encouraging listening courses at college level and creating surveys (Lotfi, 2012). As per Lotfi (2012), specialists are by definition "individuals who know a great deal about whatever territory of brain science, training, phonetics, or language instructing [our] build has a place with" (p.510). The appointed authorities gave formal master survey to investigate the substance legitimacy of the questionnaire items.

In the ebb and flow study, to guarantee, the scientists applied Cronbach's alpha and the dependability determined was 0.895 , which shows a good inside consistency. In addition, the legitimacy of the questionnaire right now affirmed by 5 English specialists who were instructed English for over 15 years and they knew about language ability particularly listening perception problems.

\subsubsection{Listening Strategies Use Questionnaire (LSUQ)}

To elicit strategies (cognitive, metacognitive or socio-affective) that participants used, Listening Comprehension Strategy Questionnaire by Chen (2010) was administered. The questionnaire adapted from Vandergrift (1997) and Goh (2000), contains 32 questions in separated parts. In LSUQ, the participants were requested to answer in a fivepoint Likert scale (ranging from $1=$ "strongly agree" to $5=$ "strongly disagree"). The questionnaire was translated into Persian by researchers and the Persian version of it was distributed among participants. The LSUQ, was created to distinguish listening comprehension strategies among Iranian EFL learners. The reliability of the LSUQ was checked by Shahrokhi, Malekian, and Sayedi (2015) via Cronbach's alpha coefficient and it was ( $r=.897)$. In this study, the Cronbach's alpha value of internal reliability of the instrument was 0.864 which is acceptable. The validity of LSUQ was confirmed by those who validated Q-BELLP.

\subsection{Information Collection}

In order to elicit relevant information from the respondents, the researchers administered the OQPT to realize the participants' homogeneity level. Then 60 learners out of 80 were randomly selected as the target participants. The researchers indeed administrated the OQPT to students to determine their level of English proficiency. As one of the researchers was taught in the high school, the students were available to him. It should be mentioned that ethics board approval was not necessary since the researcher was one of the members of the institute. Then students completed the ethical clearance strategy which included requesting permission from the students' institution and the students' written consent. It means that all selected participants filled out a consent letter that showed they voluntarily and satisfactorily participated in this study. Afterwards, the Q-BELLP was administered to distinguish listening comprehension problems among the participants. After that, LSUQ was administered to elicit what strategies (cognitive, metacognitive or socio-affective) participants used. The participants answered Q-BELLP and LSUQ in 30 and 35 minutes, respectively.

\subsection{Information Analysis}

All data were analyzed using SPSS (Version 25). To address the first research question, descriptive statistical methods including mean, frequency, and percentage were used to investigate the problems that Iranian advanced EFL learners have in listening comprehension. Moreover, Pearson correlation coefficient test was run to check the relationship between listening problems and listening strategy use scores.

\section{Results}

To address the inquiry in regards to listening comprehension problems, the mean for all items and furthermore for the whole subscales were registered. This scale incorporates six sub-classifications named process, input, listener, task, 
affect, and context problems. Table 1 uncovers that the total methods identified with Input $(M=3.035)$ and Affect subscales $(\mathrm{M}=3.006)$ were higher than the methods for other people.

Table 1. Descriptive statistics for related items to process, input, listener, task, affect, and context problems subscale

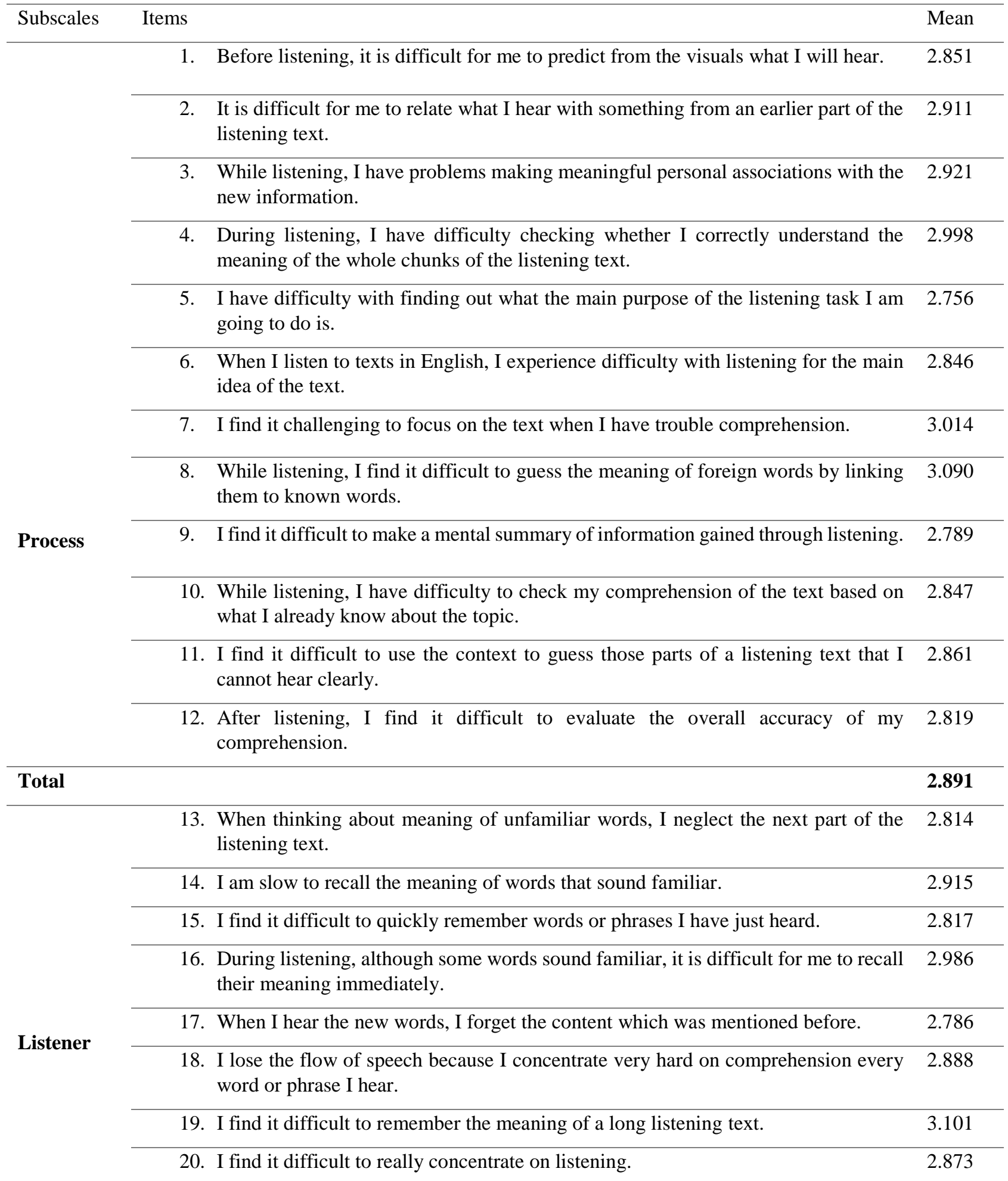


21. I have difficulty comprehending the listening text because I don't know which 2.795 strategy to use while listening.

22. I have difficulty comprehension a listening text because I cannot understand every 2.799 single word I hear.

Total

23. I find it difficult to do listening tasks, such as filling a grid, for which I need to draw 2.986 on specific information from the text.

Task

24. I find it difficult to do listening tasks for which I need to combine information to 2.678 make generalization while listening to the text.

25. I find it difficult to answer Wh-questions in a listening task.

Total

2.854

26. I find it difficult to understand listening texts in which there are too many unfamiliar 3.099 words.

27. I find it difficult to understand the meaning of words which are not pronounced 3.021 clearly.

28. I find it difficult to understand listening texts which have difficult grammatical 3.008 structures.

29. I find it difficult to understand well when speakers speak too fast. 3.013

30. Unfamiliar stress and intonation patterns of English interfere with my listening 2.998 comprehension.

Input

31. I find it difficult to understand the listening text when speakers speak with varied 3.012 accents.

32. I find it difficult to understand the listening text when the speaker does not pause 3.019 long enough.

33. I find it difficult to interpret the meaning of a long listening text. 3.009

34. I have difficulty comprehension speakers with unfamiliar accents. 3.019

Total

3.022

35. I stop listening when I have problems in comprehension a listening text. 3.011

36. If I don’t arrive at a total comprehension of an oral text, I feel disappointed. 3.068

37. I find it difficult to reduce my anxiety before doing the listening task. 2.948

Affect 38. Before doing listening comprehension tasks, I fear that I cannot understand what I 3.020 will hear.

Total

39. Unclear sounds resulting from a poor-quality CD-player interfere with my listening 2.898 comprehension.

Context

40. Unclear sounds resulting from poor acoustic conditions of the classroom interfere 2.879 with my listening comprehension.

Total

*Mean values 1-2.4 (low), 2.5-2.8 (moderate); and 2.9-3.1 (high) level 
Process Subscale. The highest mean was for the item, "I find it challenging to focus on the text when I have trouble comprehension." $(M=3.014)$, followed by the item, "While listening, I find it difficult to guess the meaning of foreign words by linking them to known words" $(M=3.009)$. The lowest mean scores were, "I have difficulty with finding out what the main purpose of the listening task I am going to do is" $(M=2.756)$. So, from this, it can be said that the main challenge encountered when learning a new language is focusing on a text when there is trouble in comprehension the given text.

Listener Subscale. The greatest mean belongs to "I find it difficult to remember the meaning of a long listening text" ( $M=3.101)$ followed by "During listening, although some words sound familiar, it is difficult for me to recall their meaning immediately" ( $M=2.986)$. The result showed that learners find it difficult remembering the meaning of a long listening text.

Task Subscale. In the Task problem sub-dimension, highest $(M=2.961)$ and lowest $(\mathrm{M}=2.635)$ mean belongs to "I find it difficult to do listening tasks, such as filling a grid, for which I need to draw on specific information from the text." and "I find it difficult to do listening tasks for which I need to combine information to make generalization while listening to the text", respectively.

Input Subscale. Another subscale was Input. Considering Input as a vital sub-category of listening problems, it can be observed that students considered most of the items problematic; however, the item "I find it difficult to understand listening texts in which there are too many unfamiliar words" received the highest mean $(M=3.099)$. The lowest mean of this sub-category, was related to the item "Unfamiliar stress and intonation patterns of English interfere with my listening comprehension" ( $\mathrm{M}=2.998)$.

Affect Subscale. All three items of Affect sub-dimension were problematic for the participants. However, if one looks at the Table 1, it can be easily observed that the highest mean $(\mathrm{M}=3.068)$ belongs to "If I don't arrive at a total comprehension of an oral text, I feel disappointed." Moreover, the item "I find it difficult to reduce my anxiety before doing the listening task" received the lowest mean $(\mathrm{M}=2.948)$.

Context Subscale. The last subcategory of listening comprehension problems checked in this research is context problem which consisted of two items, and both items had a mean of nearly 2.80 which indicates that the level of this subscale among the learners is not salient. The utmost envisaged context problem as observed in Table 1 is "Unclear sounds resulting from a poor-quality CD-player interfere with my listening comprehension" $(\mathrm{M}=2.898)$.

\subsection{Listening Strategies Usage Questionnaire}

The means for each LSUQ are provided in Table 2. The greatest total mean is related to meta-cognitive strategies $(M$ $=3.26$, followed by socio-affective strategies $(M=3.24)$ and the last and total mean belongs to cognitive strategies $(M=3.13)$.

Table 2. A summary of EFL learners' levels of listening strategy use

\begin{tabular}{ll}
\hline Strategies & Mean \\
\hline Cognitive Strategies & 4.18 \\
\hline Meta-Cognitive Strategies & 4.38 \\
\hline Socio-affective Strategies & 4.26 \\
\hline
\end{tabular}

Figure 1 illustrates the mean of participants' Listening Strategy Use. As it can be easily observed, the highest mean belongs to Meta-Cognitive Strategies followed by Socio-affective Strategies. 


\section{Mean}

\section{4}

4.35

4.3

4.25

4.2

4.15

4.1

4.05

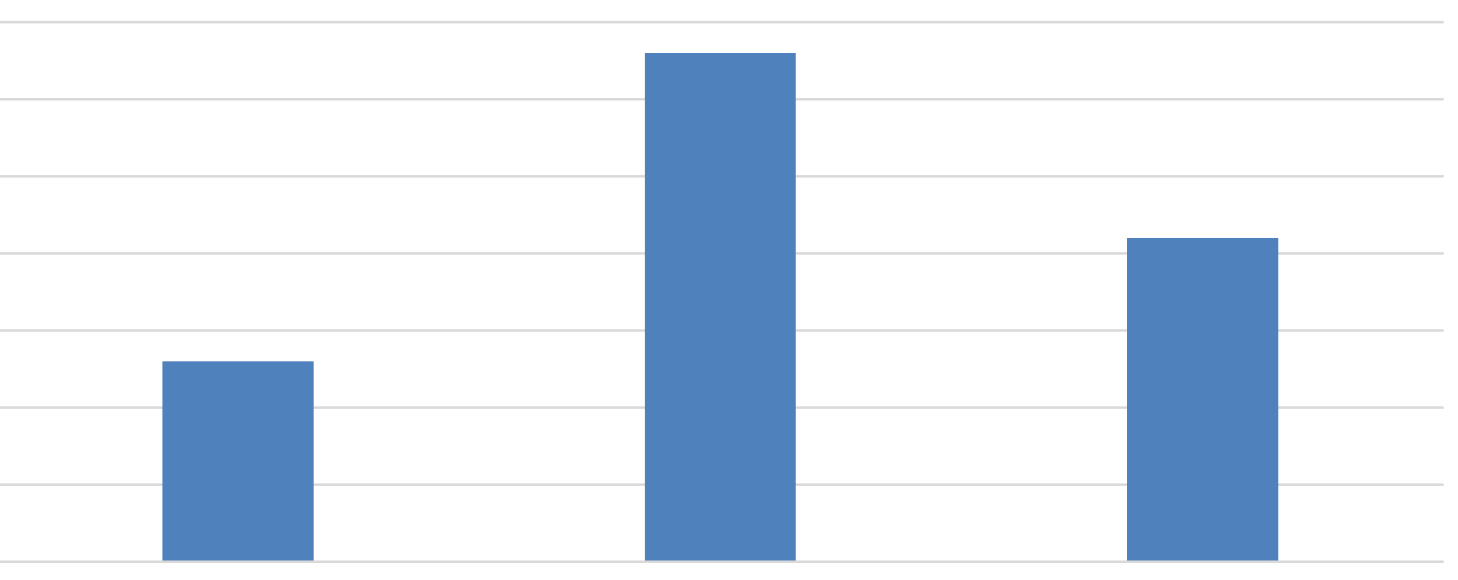

Cognitive Strategies Meta-Cognitive Strategies Socio-affective Strategies

Figure 1. Participants' mean of listening strategy use

\subsection{Relationship between Listening Strategies and Listening Problems}

Table 3 shows the connection coefficients for the connections between the EFL students' listening problems and the various sorts of listening techniques. An estimation of precisely 1.0 methods, there is an ideal positive connection between the two factors. For a positive increment in one variable, there is likewise a positive increment in the subsequent variable. An estimation of - 1.0 methods, there is an ideal negative connection between the two factors. This shows the factors move in inverse ways-for a positive increment in one variable, there is a reduction in the subsequent variable. On the off chance that the connection is 0 , there is no connection between the two factors. The quality of the relationship changes in degree is dependent on the estimation of the connection coefficient. For instance, an estimation of 0.2 shows there is a positive connection between the two factors, however it is frail and likely immaterial. Specialists don't consider relationships noteworthy until the worth outperforms in any event 0.8 . Be that as it may, a connection coefficient with an absolute value of 0.9 or more noteworthy would speak to an exceptionally solid relationship.

Table 3. Correlation coefficients for the relationships between listening strategies and listening problems

\section{Cognitive Strategies Meta-Cognitive Strategies}

Socio-affective

Strategies

\begin{tabular}{lllll}
\hline & \multicolumn{1}{l}{ Process } & $.933^{* *}$ & $.696^{* *}$ & $.859^{* *}$ \\
\cline { 2 - 5 } & Input & $.699^{* *}$ & $.679^{* *}$ & $.678^{* *}$ \\
\cline { 2 - 5 } $\begin{array}{l}\text { Pearson } \\
\text { Correlation }\end{array}$ & Listener & $.543^{* *}$ & $.653^{* *}$ & $.473^{* *}$ \\
\cline { 2 - 5 } & Task & $.496^{* *}$ & $.399^{* *}$ & $.858^{* *}$ \\
\cline { 2 - 5 } & Affect & $.989^{* *}$ & $.696^{* *}$ & $.676^{* *}$ \\
\hline
\end{tabular}

The relationship between listening problems (i.e., process and affect problems) and cognitive strategies was a perfect uphill (positive) linear relationship $(r=.933$ and .989), and this relationship was of statistically significance. 
Moreover, process and affect problems appear to have a strong uphill (positive) linear relationship with Socio-affective Strategies $(r=.859$ and .858$)$. Likewise, other listening problems was found to have a moderate (positive) linear relationship with Cognitive, Meta-Cognitive, and Socio-affective strategies. Therefore, these outcomes showed that by increasing the cognitive strategies, process and affect problems would be decreased. To find out whether variance in listening strategies could account for variance in listening problems, one needs to examine the multiple regression analysis table below.

Table 4. Model summary for multiple regression

\begin{tabular}{llll}
\hline $\mathrm{R}$ & $\mathrm{R}$ Square & Adjusted R Square & Std. Error of the Estimate \\
\hline $.969^{\mathrm{a}}$ & .933 & .939 & 1.73228
\end{tabular}

In Table 4, the value given under the $\mathrm{R}$ Square column shows how much of the variance in listening problems is explained by listening strategies. The value here is .933 , which means that listening strategies accounted for 93 percent of the variance in listening problems scores. To examine the statistical significance of this result, Table 6 should be consulted.

Table 5. Statistical significance of the multiple regression results

\begin{tabular}{llllll}
\hline & \multicolumn{2}{l}{ Unstandardized Coefficients } & Standardized Coefficients & T & Sig. \\
\cline { 2 - 7 } & $\mathrm{B}$ & Std. Error & Beta & & \\
\hline (Constant) & 7.148 & 2.685 & & 2.911 & .004 \\
\hline Cognitive Strategies & .813 & .098 & .819 & 7.898 & .000 \\
\hline Meta-Cognitive Strategies & .000 & .069 & -.003 & -.008 & .993 \\
\hline Socio-affective Strategies & .369 & .189 & .248 & 2.294 & .039 \\
\hline
\end{tabular}

To look at the prescient forces of Cognitive, Meta-Cognitive, and Socio-affective strategies, the qualities under Beta in the section named institutionalized coefficients ought to be checked. Looking down this segment, one could see that the biggest worth was the one for Cognitive strategies. Cognitive strategies in this manner made the strongest unique contribution to explaining listening problems. The applicable Beta incentive for Socio-affective strategies was the second most noteworthy incentive out there, showing that it made to a lesser extent a commitment. The other worth was - .003 for Meta-Cognitive; this listening strategy' contributions to the forecast of listening problems was little.

For each of these variables, the value under the column marked Sig. must be checked. This shows whether this variable was making a statistically significant unique contribution to the equation or not. Cognitive strategies and Socioaffective strategies had a Sig. value less than the significance level (.05); it could thus be concluded that among the three different types of language learning strategies, Cognitive strategies and Socio-affective strategies could significantly predict listening problems of the EFL learners.

\section{Discussion}

Listening is indispensable to instructive and scholastic improvement for learners at any degree of training. It has been communicated by specialists that among the four language aptitudes, listening is the most routinely utilized language capacity in the classroom (Vogely, 1998). The two instructors and learners perceived the essentialness of listening understanding for scholastic achievement in instructive settings. Despite the fact that researchers (Rost, 1994; Tahmasbi, Hashemifardnia, \& Namaziandost, 2019; Vogely, 1998) place that listening assumes a focal job in correspondence just as in learning and cognizance, it is essential to comprehend the problems students of another language experience while listening. It depends on this need this examination was directed. It researched the listening problems experienced by Iranian development EFL students. 
Discoveries of the examination bolster the after-effects of Juan and Abidin (2013) who researched the English listening perception problems of worldwide college students from China in Universiti Sains Malaysia (USM) who found that the emphasis of local speakers restricted the correct cognizance of the listening content by the students. One of the examinations about learners' listening perception problems was directed by Hamouda (2012) with 60 EFL Saudi students. The outcomes uncovered that the learners' significant listening perception problems were elocution, speed of discourse, deficient jargon, diverse highlight of speakers, absence of focus, uneasiness, and awful nature of recording.

Furthermore, the way where words are articulated is likewise one of the problems which students of a foreign language experience. The consequence of this exploration uncovered that students of a foreign language frequently think that it's hard to comprehend the importance of vocabularies which are not accurately articulated. The respondents of this examination concurred this is one of the serious problems they face while learning a foreign language. This finding agreed with the discoveries of an investigation which was directed by Hassan (2000) in an EFL setting through a survey to decide learners' self-saw listening problems. One of the problems distinguished by Hassan (2000) was problems coming about because of hazy way to express words.

Another significant listening problem of students of a foreign language is discourse rate. This was uncovered by the consequences of research as the respondents of this examination concurred that they think that it's hard to comprehend a listening content when the speaker talks quick without stopping sufficiently long to permit them process and understand what they have tuned in to; the respondents said that this problem close by long content adds up to powerlessness to grasp the content. The discoveries of this exploration affirm those of Goh (1999) just as Flowerdew and Miller (1992) which likewise delineated that discourse rate is additionally viewed as a significant problem for L2 students. Practically all of Flowerdew and Miller's (1992) and Goh's (1999) study, 78\% of the members and members in the two journals and meetings announced that their basic problem was the quick English discourse rate.

The last info problem perceived right now the problem of content length. The members of this examination agreed that they think that it's hard to see long messages when learning another language particularly when the long content contains a great deal of new words. As a rule, it will in general be said that the essential information problems experienced by learners are discourse rate, content length, new emphasis, and wrong way to express words.

Problems identified with influence and undertaking were likewise recognized right now a portion of the listening problems experienced by students of another language. In spite of the fact that these problems had the most reduced mean scores, they couldn't be neglected as the respondents of this examination uncovered that they thought that it was hard to do listening undertakings, for example, filling a framework, for which they expected to draw on explicit information from the content. The respondents of the present examination concurred that such an errand gives them uneasiness and this nervousness they can't lessen before taking part in the assignment. The ramifications of this is the learners can barely understand on the grounds that they are in a precarious perspective which won't license cognizance of the listening content; along these lines, it tends to be said the perspective of the student assumes a job in the perception of a listening content.

It very well may be noted from the aftereffect of this examination that all the problems talked about above influence the handling of a foreign language by students as the respondents of this investigation concurred that they think that it's difficult to concentrate on the content when they experience difficulty appreciation the content. What's more it tends to be closed from the aftereffect of this examination that while listening, students of a foreign language think that it's hard to figure the significance of obscure words by connecting them to known words, this likewise drives the students to disregard the following piece of the listening content since they are frequently busy with intuition about the importance of new words.

As to listening problems experienced by learners of a foreign language, it very well may be seen that these students select strategies which they accept can upgrade a superior appreciation of the listening content; these techniques incorporate subjective methodologies, metacognitive systems, and socio-affective strategies. Right now, it was indicated that the most regularly utilized strategy among the respondents of the investigation is the metacognitive systems which had the most noteworthy mean score among the three techniques estimated. These students express that while learning another language they listen to catchphrases and utilize their experience and past information to comprehend the listening content. 
Notwithstanding what has been recently referenced, different creators have talked about methods for helping students improve their listening appreciation. Dark colored (1992) proposed a strategy that consolidated building up the students' phonological code and helping them use settings to make expectations. Buck (1995) proposed utilizing preinformative and open exercises, following an instructive structure by Littlewood (1998). This included helping students build up an office with quick regular discourse and utilize great listening techniques. Field (2008) proposed a methodology that contemplated students' listening problems and recommended a progression of activities for working on listening sub-skills in short miniaturized scale listening works out.

\section{Conclusion}

Listening comprehension has been neglected in research and practice until quite recently. Even now, we can't say that listening comprehension research abounds in the literature when compared to other skills. This is why some researchers call listening "Cindrella skill" in second language learning (Nunan, 1997, p.46). However, it is true that listening is vital in language learning in that it provides input for the learner. Without comprehending inputs, students can't learn anything.

Research results have permitted us to come to the accompanying end results:

1. Learners at senior secondary high schools experience different sorts of listening problems in learning understanding, for example, new words, the length of the verbally expressed content, speed rate, an assortment of accents, absence of focus and articulation.

2. A few proposals that could be utilized for educators and learners to experience listening understanding problems incorporate adjusting and improving listening materials, and improving instructors' classroom methods with respect to the instructors. With respect to learners, they can mitigate their own challenges by improving English capability, and improving listening methodologies.

It very well may be concluded from this finding on the use of learning methodologies that the utilization of learning systems by learners right now admirable as the degree of use for every one of the techniques is moderate. This furthermore suggests there is still opportunity to get better on the usage of these systems to improve better perception of another language as analysts right now (Karami \& Bagheri, 2014; Rahimirad \& Zare-ee, 2015) have revealed that these learning strategies have a crucial positive result on the learning of another language.

The information got from this investigation has suggestions for language instructors. Instructors, as adding information to the strategies prompting listening cognizance in the foreign language could assist educators with examining what listening involves. After the investigation of the strategy, educators can direct students in the utilization of elective systems for listening. Accordingly, these strategies and techniques may give experiences to instructors to utilize in planning the listening parts of their projects. Then again, creating scientific categorization of the techniques utilized by capable audience members could enable the instructors to utilize these methodologies to improve the listening propensities for poor audience members.

Future studies may consider the following directions:

1. The present study needs to be carried out with large sample because the sample size was too small to generalize an overall conclusion applying to all EFL learners.

2. A standardized inventory of listening problems could be created to provide instructors and learners with an efficient way to diagnose strategy difficulties.

3. The present study needs to be studied in different English learning contexts in Iran.

4. Further research needs to be conducted with more comprehensive samples including the primary, secondary, and preparatory levels in order to get a complete picture of the problem. It is hoped that the results of this study will contribute to improving the teaching and learning in the field of listening comprehension in Iran.

To conclude, listening is vital not only in language learning but also in daily communication. However, being one of the teachers at high school, I can clearly see the situation of teaching and learning English. Listening comprehension seems to be the weakest skill and students encounter various kinds of listening problems. This study is done in the hope. 


\section{References}

Abedi, P., Keshmirshekan, M. H., \& Namaziandost, E. (2019). The comparative effect of flipped classroom instruction versus traditional instruction on Iranian intermediate EFL learners' English composition writing. Journal of Applied Linguistics and Language Research, 6(4), 43-56. http://www.jallr.com/index.php/JALLR/article/view/1036

Abedi, P., Namaziandost, E., \& Akbari, S. (2019). The impact of flipped classroom instruction on Iranian upperintermediate EFL learners' writing skill. English Literature and Language Review, 5(9), 164-172. https://doi.org/10.32861/ellr.59.164.172

Bidabadi, F., \& Yamat, H. (2011). The relationship between listening strategies used by Iranian EFL freshman university students and their listening proficiency levels. English Language Teaching, 4(1), 26-32. doi: 10.5539/elt.v4n1p26

Buck, G. (1995). How to become a good listening teacher. In D. J. Mendelsohn, \& J. Rubin (Eds.), A guide for the teaching of second language listening (pp. 113-131). San Diego, CA: Dominie Press, Inc.

Byrnes, H. (1984). The role of listening comprehension: A theoretical base. Foreign Language Annals, 17(4), $317-$ 329. https://doi.org/10.1111/j.1944-9720.1984.tb03235.x

Chamot, A. U., \& O'Malley, J. M. (1987). The cognitive academic language learning approach: A bridge to the mainstream. TESOL Quarterly, 21(2), 227-249. https://doi.org/10.2307/3586733

Chen, A. H. (2013). EFL listeners' strategy development and listening problems: A process-based study. The Journal of Asia TEFL, 10(3), 81-101.

Chen, K. T. (2010). University EFL learners' awareness of metacognitive listening comprehension strategies in Taiwan. Cross-University International Conference on English Teaching, Taipei, Taiwan.

Etikan, I., Musa, S. A., \& Alkassim, R. S. (2016). Comparison of convenience sampling and purposive sampling. American Journal of Theoretical and Applied Statistics, 5(1), 1-4. doi: 10.11648/j.ajtas.20160501.11

Field, J. (2008). Listening in the language classroom. Cambridge: Cambridge University Press.

Flowerdew, J., \& Miller, L. (1992). Student perceptions, problems and strategies in second language lecture comprehension. RELC journal, 23(2), 60-80. https://doi.org/10.1177/003368829202300205

Goh, C. C. M. (1999). How much do learners know about the factors that influence their listening comprehension? Hong Kong Journal of Applied Linguistics, 4(1), 17-41. https://pdfs.semanticscholar.org/ee28/87c82a7d39405935bdaabc040f6cfba57efb.pdf

Goh, C. C. M. (2000). A cognitive perspective on language learners' listening comprehension problems. System, 28(1), 55-75. doi:10.1016/S0346-251X(99)00060-3

Graham, S., \& Santos, D. (2015). Strategies for second language listening: Current scenarios and improved pedagogy. Palgrave Macmillan, London.

Guo, N., \& Wills, R. (2006). An investigation of factors influencing English listening comprehension and possible measures for improvement. Paper presented at the AARE Annual Conference Parramatta. https://www.aare.edu.au/data/publications/2005/guo05088.pdf

Hamouda, A. (2012). Listening comprehension problems-voices from the classroom. The Language in India, 12(2), 1-49. http://hrmars.com/admin/pics/1882.pdf

Hasan, A. S. (2000). Learners' perceptions of listening comprehension problems. Language, Culture and Curriculum, 13(2), 137-153. https://doi.org/10.1080/07908310008666595

Hashemifardnia, A., Namaziandost, E., Shafiee, S. (2018). The effect of implementing flipped classrooms on Iranian junior high school students' reading comprehension. Theory and Practice in Language Studies, 8(6), 665-673. http://dx.doi.org/10.17507/tpls.0806.17 
Holden, W. R. (2004). Facilitating listening comprehension: Acquiring successful strategies. Bulletin of Hokuriku University, 28 https://pdfs.semanticscholar.org/d766/2d12f661ed0b96f7e67d6b4b2c8ca30a0e17.pdf

Juan, W. X., \& Abidin, M. J. Z. (2013). English listening comprehension problems of students from China learning English in Malaysia. Language in India, 13(4), 14009-14022. https://pdfs.semanticscholar.org/a824/d5aac5b6f65a12b8c1c3a0e2ef647fb251b7.pdf? ga=2.63025199.16138 39513.1582715230-1722624921.1551015843

Karami, S., \& Bagheri, M. (2014). Operationalizing teachers' emotional attitudes towards their students, colleagues and workplace: Result from an EFL context. Journal of Language \& Literature, 5(1), 140-149. https://www.semanticscholar.org/paper/Opertionalizing-teachers\%E2\%80\%99-emotional-attitudes-theirKarami-Bagheri/250a2d2167e8027fd8c70eade2373cfa4035a9ee

Kassem, H. M. (2015). The relationship between listening strategies used by Egyptian EFL college sophomores and their listening comprehension and self-efficacy. English Language Teaching, 8(2), 153-169. doi:10.5539/elt.v8n2p153

Lau, K. L. (2016). Strategy use, listening problems, and motivation of high- and low-proficiency Chinese listeners. The Journal of Educational Research, 110(5), 503-514. https://doi.org/10.1080/00220671.2015.1134421

Littlewood, W. (1998). Communicative activities. Cambridge: Cambridge University Press.

Lotfi, G. (2012). A questionnaire of beliefs on English language listening comprehension problems: Development and validation. World Applied Sciences Journal, 16(4), 508-515. https://pdfs.semanticscholar.org/fe11/fab693e27751e12be532c9e981c4f609f841.pdf

Mendelson, D. J. (1994). Learning to listen. USA: Dominie Press.

Mirshekaran, R., Namaziandost, E., \& Nazari, M. (2018). The effects of topic interest and 12 proficiency on writing skill among Iranian EFL learners. Journal of Language Teaching and Research, 9(6), 1270-1276. http://www.academypublication.com/ojs/index.php/jltr/article/view/jltr090612701276

Namaziandost, E., \& Ahmadi, S. (2019). The assessment of oral proficiency through holistic and analytic techniques of scoring: A comparative study. Applied Linguistics Research Journal, 3(2), 70-82. https://www.journalagent.com/alrj/pdfs/ALRJ_3_2_70_82.pdf

Namaziandost, E., Hafezian, M., \& Shafiee, S. (2018). Exploring the association among working memory, anxiety and Iranian EFL learners' listening comprehension. Asian-Pacific Journal of Second and Foreign Language Education, 3(20), 1-17. https://doi.org/10.1186/s40862-018-0061-3

Namaziandost, E., \& Nasri, M. (2019a). A meticulous look at Long's (1981) interaction hypothesis: does it have any effect on speaking skill? Journal of Applied Linguistics and Language Research, 6(2), 218-230. http://www.jallr.com/index.php/JALLR/article/view/1023

Namaziandost, E., Neisi, L., Kheryadi, \& Nasri, M. (2019). Enhancing oral proficiency through cooperative learning among intermediate EFL learners: English learning motivation in focus. Cogent Education, 6(1), 1-15. https://doi.org/10.1080/2331186X.2019.1683933

Namaziandost, E., Neisi, L., Mahdavirad, F., \& Nasri, M. (2019). The relationship between listening comprehension problems and strategy usage among advance EFL learners. Cogent Psychology, 6(1), 1-19. doi: $\underline{10.1080 / 23311908.2019 .1691338}$

Namaziandost, E., Saberi Dehkordi, E., \& Shafiee, S. (2019). Comparing the effectiveness of input-based and outputbased activities on productive knowledge of vocabulary among pre-intermediate EFL learners. Asian-Pacific Journal of Second and Foreign Language Education, 4(2), 1-14. https://doi.org/10.1186/s40862-019-0065-7

Namaziandost, E., Sabzevari, A., \& Hashemifardnia, A. (2018). The effect of cultural materials on listening comprehension among Iranian upper-intermediate EFL learners: In reference to gender. Cogent Education, 5(1), 1-27. https://doi.org/10.1080/2331186X.2018.1560601 
Namaziandost, E., Shatalebi, V., \& Nasri, M. (2019). The impact of cooperative learning on developing speaking ability and motivation toward learning English. Journal of Language and Education, 5(3), 83-101. https://doi.org/10.17323/jle.2019.9809

Nasri, M., Namaziandost, E., \& Akbari, S. (2019). Impact of pictorial cues on speaking fluency and accuracy among Iranian pre-intermediate EF learners. International Journal of English Language and Literature Studies, 8(3), 99-109. https://ideas.repec.org/a/asi/ijells/2019p99-109.html

Nunan, D. (1997). Second language teaching \& learning. Massachusetts: Heinel \& Heinel Publishers.

O’ Malley, J. M., Chamot, A. U., \& Kupper, L. (1989). Listening comprehension strategies in second language acquisition. Applied Linguistics, 10(4), 418-437. https://doi.org/10.1093/applin/10.4.418

Persulessy, G. H. (1988). Listening improvements Exercises for students of English. Cambridge: Cambridge University Press.

Peterson, P. W. (2001). Skills and strategies for proficient listening. In M. Celce Murcia (Ed.), teaching English as a second or foreign language (p.69-85). Boston: Heinle \& Heinle.

Pourhosein, G. A., \& Ahmadi, M. R. (2011). A study of factors affecting EFL learners' English listening comprehension and the strategies for improvement. Journal of Language Teaching and Research, 2(5), 977988. doi:10.4304/jltr.2.5.977-988

Rahimirad, M., \& Zare-ee, A. (2015). Metacognitive strategy instruction as a means to improve listening self-efficacy among Iranian undergraduate learners of English. International Journal of Instruction, 8(1), 117-132. https://eric.ed.gov/?id=EJ1085296

Rost, M. (1994). Introducing listening. London: Penguin books.

Rost, M. (2011). Teaching and researching: Listening (2nd ed.). Taylor \& Francis, New York.

Rubin, J. (1994). A review of second language listening comprehension research. The Modern Language Journal, 78(2), 199-221. https://doi.org/10.1111/j.1540-4781.1994.tb02034.x

Serri, F., Boroujeni, A. J., \& Hesabi, A. (2012). Cognitive, metacognitive, and social/affective strategies in listening comprehension and their relationships with individual differences. Theory and Practice in Language Studies, 2(4), 843-849. doi:10.4304/tpls.2.4.843-849

Shahrokhi, M., Malekian, P., \& Sayedi, S. B. (2015). Listening comprehension ability and the use of listening strategies by Iranian pre-intermediate EFL learners. Journal of Applied Linguistics and Language Research, 2(5), 231-241. http://www.jallr.com/index.php/JALLR/article/view/100/pdf100

Shakibaei, G., Shahamat, F., \& Namaziandost, E. (2019). The effect of using authentic texts on Iranian EFL learners' incidental vocabulary learning: The case of English newspaper. International Journal of Linguistics, Literature and Translation (IJLLT), 2(5), 422-432. doi: 10.32996/ijllt.2019.2.5.47

Tahmasbi, S., Hashemifardnia, A., \& Namaziandost, E. (2019). Standard English or world Englishes: Issues of ownership and preference. Journal of Teaching English Language Studies, 7(3), 83-98. http://www.iaujournals.ir/article_665009_bc918242d35f565d74a0b19073056696.pdf

Vandergrift, L. (1997). The comprehension strategies of second language (French) listeners: A descriptive study. Foreign Language Annals, 30(3), 387-409. https://doi.org/10.1111/j.19449720.1997.tb02362.x

Vandergrift, L., \& Goh, C. C. M. (2012). Teaching and learning second language listening: Metacognition in action. Routledge, New York.

Vogely, A. (1995). Perceived strategy uses during performance on three authentic listening tasks. The Modern Language Journal, 79(1), 41-56. https://doi.org/10.1111/j.1540-4781.1995.tb05414.x 
Yaseen, S. R., \& Nimehchisalem, V. (2016). Listening comprehension problems and strategies among Kurdish EFL learners. The Iranian EFL Journal, https://www.researchgate.net/publication/311793729_Listening_Comprehension_Problems_and_Strategies_a mong_Kurdish_EFL_Learners

Ziafar M., \& Namaziandost, E. (2019). Linguistics, SLA and lexicon as the unit of language. International Journal of Linguistics, Literature and Translation (IJLLT), 2(5), 245-250. http://www.ijllt.org/linguistics-sla-andlexicon-as-the-unit-of-language/ 